\title{
ACCESSING EMOTIONS THROUGH HUMOUR IN THE CONTEMPORARY ARGENTINEAN TRANSITIONAL JUSTICE TRAJECTORY
}

\author{
// EVA VAN ROEKEL
}

ABSTRACT // This article is based on qualitative fieldwork on current human rights trials regarding crimes committed during the last dictatorship in Argentina (1976-1983). The study focuses on emotional experiences surrounding the trials in and around Argentinean federal courts and analyses these experiences from a phenomenological perspective. However, in the legal context, people's experiences of emotions related to violence are constrained due to judicial rules and social norms in general. Analysis of local humour practices related to the human rights trials provides a heuristic tool that unveils uncomfortable emotions that often remain inaccessible. Studying humour in this legal context is thought-provoking and provides alternative insights into transitional justice trajectories in Argentina. 
Sisting cholarly debates on transitional justice and reconciliation following collective violence often employ words like 'guilt', 'anger', 'forgiveness', 'sorrow', 'remorse', and 'revenge' to address the emotions of people (Arnould 2006; Bloomfield et al 2003; Elster 2004; Findlay \& Henman 2005, Minow 1998; 1999; Nino 1996; Osiel 1997; Roht-Arriaza \& Mariezcurrena 2006; Teitel 2000). Nonetheless, it often remains unclear how such different emotions are experienced in practice. The so-called Cartesian divide between reason and emotion is unfortunately still implicit in much academic work on reconciliation and transitional justice. Furthermore, when we read judicial records many of these emotions are left unspoken. Emotions seem to have been forgotten, or deliberately left out because they are considered hazardous and subjective (Lupton 1998: 85). Notwithstanding that, the law is part of a system of cultural norms that influences choices about behaviour, and it is therefore impossible to consider emotional effects as external to the law (Finkel \& Parrott 2006: 87). Subsequently this article springs from the premise that reason and emotion are mutually inclusive. Emotions are not disruptions of our otherwise calm and reasonable experience; they are at the very heart of every experience and a fundamental part of being alive (Finkel \& Parrott 2006: 64; Lupton 1998: 4; Nussbaum 2004: 5; Solomon in Wierzbicka 1999: 18). Understanding the Argentinean human rights trials with a focus on felt experiences regarding collective violence continues the contestation of the long-lasting neglect or, rather, contempt towards emotions in positivistic thought in general and Western law in particular (Bandes 1999; Bandes \& Blumenthal 2012; Maroney 2006; Minow 1999).

In addition, this article argues that when researching a novel social environment, humour practices can offer alternative insights into the various ways that people deal with collective violence, and provide insight beyond the official and socially accepted emotions regarding the violent past and present trials in Argentina. The state, however, does not sanction these emotions in the current trials; as we will see, they are articulated by other means. Moreover, this article sees humour as a heuristic 'tool' to access these alternative and often silenced emotional experiences. It sees local practices of humour as a methodological instrument to research uncomfortable emotions from a sensorial, bodily and discursive perspective. Vengeance, especially, is often considered an 'uncivilized' emotion. Also, guilt and shame are both uncomfortable emotions and are difficult to acknowledge in public and difficult to feel for the people I met in the field. Therefore I have decided to change the names of the informants in this article in order to protect anonymity, but persons with a public profile and those who are officially involved in the described human rights trials have not been altered.

Finally in line with Al-Mohammad, we should explore the tensions between what we see and experience and what we cannot, and how this tension feeds into our lives (2011:
134). Instead of staring blindly at the difficulties of grasping other people's emotions, we must explore what we do perceive in the course of fieldwork, and discuss their epistemological and methodological implications. As you will see in the next empirical sections, ridicule articulated by a satirical column, a smothered laugh, derisive games and the amused response of a human right's lawyer to a smell on a researcher's body can be understood as such alternative hermeneutic resources (Cerwonka \& Malkki 2007: 36). They can tell us something about how people feel when direct questions have not been asked. Proceeding from such bodily awareness in an intersubjective field, this hermeneutic principle for the construction of knowledge on emotions will, however, be partial. Thus, fully understanding the emotional experience of alleged perpetrators and victims of political violence and state terrorism and its judicial aftermath is impossible. However, instead of ignoring humour and these emotions, if we pay attention to them we will better understand the dialectic between official justice at the courts and justice-as-lived, which is at the core of my ongoing research project on the Argentinean transitional justice trajectory.

\section{A NEW DISAPPEARANCE}

After decades of political violence and military interventions in Argentina (Robben 2005), in a political environment of escalating violence, a civil-military regime once more seized power on March 24, 1976. Following more than seven years of state repression involving illegal detentions, torture, assassinations and the disappearance of thousands, a democratic government was elected in 1983. The Alfonsín government almost immediately initiated a process of truth telling and retributive justice. It established the National Commission on the Disappearance of Persons (CONADEP) and opened prosecution of the nine highest members of the three successive military juntas, Legal Case 13/84. After this brief official moment of truth and justice, while prosecutions against middle rank military officers continued, civil-military tensions rose. The rising turmoil forced President Alfonsín to execute two amnesty laws for the armed forces: the Full Stop Law and the Due Obedience Law. ${ }^{1}$ During the 1990s, under President Menem, the former junta members were pardoned and families of the disappeared received state compensations. However, the Argentinean truth, justice and memory initiatives were not put on a hold following these payments. On the contrary, the social struggle against oblivion and impunity continued and the need for retribution still lingered for several family members and survivors.

\footnotetext{
${ }^{1}$ In 1986 the Full Stop Law (decree 23.492) set a deadline for the filing of new charges of alleged perpetrators of the last dictatorship. In 1987 the Due Obedience Law (decree 23.521) undid responsibility for crimes committed by the lower rank and file. The law argued that they acted under subordination to a superior authority and followed their orders.
} 
When the Kirchner government came into power in 2003, human rights groups in Argentina gained momentum in their long struggle for legal justice for the crimes committed during the last dictatorship. After the Supreme Court annulled former amnesty laws in 2005, hundreds of accusations and thousands of victims' cases began flooding the Argentinean judicial system. Almost 1,500 people, mainly military officers of all ranks and files, have since been charged at federal courts throughout the country for crimes against the disappeared and survivors of the former clandestine detention centres (CDC). The illegal adoptions of babies born in CDCs and cases of notorious death flights above the Rio de la Plata and the South Atlantic are also included, all under the umbrella of crimes against humanity and the legally hazardous term of genocide in international law regarding political violence and state terrorism in Argentina (Lozada 2008: 72-75).

In September 2006 in La Plata, a provincial town near Buenos Aires, just one day before the Tribunal No. 1 announced the verdict against former police officer Miguel Etchecolatz for crimes against humanity, a witness, Julio López, disappeared. López was a retired construction worker illegally detained during the last dictatorship. For several weeks, police squads searched for him but seemed to have hit a dead end. ${ }^{2}$ In the year 2013 Julio López has still not reappeared, and the ones responsible for his disappearance are still unknown. A protest group of López's supporters emerged and organized large rallies in his hometown La Plata. Pictures of his silhouette and slogans regarding his whereabouts have appeared all over the streets of Buenos Aires and La Plata. ${ }^{3}$ This sinister 'new' disappearance of a witness, at a time when legal justice for thousands of the disappeared is the very thing aimed for, has become a stepping stone for many rumours and conspiracy theories (Van Drunen 2010: 234). Julio López has also become a matter of serious concern for a local magazine Barcelona which elaborates on the disappearance in a humorous column. Since 2008 Barcelona has been publishing a column on the fictional whereabouts of López that satirises this disappearance under the Kirchner government. Entitled 'Day by Day: What has been done in the search for Julio López?' the column ridicules a lack of accountability for López's disappearance and amnesia among local media and the government. It voices the tensions between the human rights policies of the Kirchner government and this new form of 'injustice with impunity'.

During my first short stint of fieldwork in Buenos Aires in 2009 , I worked briefly with a local research team on

\footnotetext{
${ }^{2}$ See newspaper clipping: Missing Witness Awakens Dark Past by Trigona, 22-10-2006.

${ }^{3}$ Ana Longoni, an Argentinean art historian, spoke at a conference about the recent cultural practices regarding López disappearance. She called it artistic activism. I attended this conference at IDES, an academic research institute on April 16th 2010, Buenos Aires. See also online publication Todos somos López. Available at: www.cuadernos.inadi.gob.ar [Accessed on 24 October 2011].
}

an evaluation project of the human rights trials regarding the last dictatorship, with specific emphasis on a witness protection programme. After the disappearance of Julio López, and the emergence of new threats against future witnesses, in 2007 the government initiated a programme to protect witnesses in human rights trials. One day during a break one of my fellow researchers, Olivia, pointed to the López column in Barcelona and asked me, 'Have you seen the latest Day by Day?' I told Olivia that I had not read the column or even seen the magazine yet. With a smothered laugh she replied that it would probably be too difficult for me anyway to understand such jokes. I was puzzled. What could be so funny about a recent disappearance?

After eight months in the field I had completely forgotten about the column on Julio López. Then, my eye accidentally fell on a copy of Barcelona in a kiosk. On the back page I read the headline, 'August 2nd: National Son of a Bitch Day.' Underneath were nine black-and-white photos of military officers involved in current human right trials, each captioned 'Happy Son of a Bitch Day'. I thought this hinted at the commercial excesses of these contrived celebrations, like Secretary's Day and Teacher's Day, which both happen in September. Recalling what Olivia had said about the López column, I bought a copy of the magazine. After months of fieldwork and trying to understand what justice means for survivors, family members of the disappeared and alleged perpetrators, the faces of the military officers made me stifle an almost inaudible laugh. I felt a mix of discomfort and pleasure, as if I were not supposed to laugh. That was the moment, I think, that I started to grasp the complexity of Barcelona's humour that Olivia had hinted at.

In retrospect, I am sure my suppressed laugh indicated that I was finally starting to comprehend this gallows humour. This humour may also reflect the difficulty with defining boundaries of complicity and accountability in the grey areas following collective violence and state terrorism. Moreover, this unexpected laughter at the kiosk while looking at those pictures positioned me morally. Endorsing a certain humour implies complicity and belonging. Approving a joke is accepting a moral point of view on a certain matter, and it constructs a sense of solidarity (Buckley 2003: 5). I believe a requirement for any deep comprehension in contexts of previous collective violence involves liberation from official memorial culture, as Huyssen accurately argues. He suggests that we must look for alternative narrative strategies, including irony, shock and black humour (Huyssen 2001: 39). Satirical humour fuses evaluative, judgmental and emotive dimensions (Hutcheon 1994: 37) and, as Oring notes, can unveil the uncomfortable to a certain extent (Martin 2007: 43). Through my long-term fieldwork I gradually began to decode humour practices, which discerned other, more uncomfortable emotional experiences regarding the violence, the memories, and the justice practices of the last 30 years in Argentina. Humour practices, such as in the Argentinian magazine Barcelona, provide us with a 
tangible insight into such emotions.

However, emotions are not simply out there or inside us, waiting to be found. Emotions are shaped in relation to others in a particular environment, and hence experienced through the conscious body. Rosaldo sees emotions as social practices organized by stories that we both enact and tell that are structured by our forms of understanding (1984: 143). Other important contributions to the anthropological understanding of emotions have shown how emotional experiences are embedded in a particular locale and are a product of social interaction, and also the emotions of the researcher (Abu-Lughod 1986; Beatty 2010; Briggs 1970; Davies \& Spencer 2010; Leavitt 1996; Lutz 1988; Lutz \& White 1986; Rebhun 1999; Rosaldo 1984; Scheper-Hughes 1992; White 2010; Wikan 1990). Beatty, however, argues that the ethnographer's emotions lose their explanatory power away from home as they belong to different narratives (2010: 433). There will always be fundamental differences between the fieldworker's emotions and those of his or her informants (Hage 2010: 144-149). Yet knowledge about emotions is neither purely about the other, nor purely about oneself (Corin 2007: 243). It is about the intersubjective field in which we experience such emotions, where the researcher's felt experiences are meaningful data (Lorimer 2010: 100; Luhrmann 2010: 213). Embodied knowledge, accumulated by being-in-the-world, is intrinsic to the process of learning about emotions, about oneself and about others (Gieser 2008: 303). Such a phenomenological approach to social life starts with the personal and the affective and shows how our understanding emerges out of interactions and experiences with others in the everyday world (Jackson 1989: 5).

Also what or how people feel is often different from what they express in public, or what they reveal in an interview or informal conversation. I often asked the people I had come to know what emotions they felt were important in the transitional justice trajectory in Argentina. The direct descriptions of their emotions in relation to the human rights trials were very valuable, but they were not always in line with my own participatory observations of others, or of my own emotional experiences. Lila AbuLughod marvellously describes immoral feelings: those feelings that stand outside the official system of honour in a Bedouin community, and can only be communicated through the language of poetry (1986:256). In line with her argument, I believe there is sometimes a discrepancy indeed between what we believe we ought to feel, what we desperately try to feel, and what we actually manage to bring ourselves to feel (Rebhun 1999: 187), and this can be communicated, in this case, through humour. The next empirical section will elaborate on this notion.

\section{JUSTICE AT PLAY}

It is spring. I have just returned from a few days away from fieldwork and I feel mellow and able to submerge myself again in another human rights trial. This mellow state seems in slight contrast with the field of legal justice after state violence. But the warm spring sun cultivates my relaxed mood, and I am eager to see Emilio Váldez whom I have not seen in a while. Emilio is affiliated with one of the splinter parties of the left. His uncle disappeared in 1977. We often go together to court or street events. Today we are attending the opening of the trial against former police officer Luis Patti, de facto President Reynaldo Bignone of the last dictatorship and three other defendants at Tribunal No. 1 at the Federal Court in San Martin. All men stand accused of crimes against humanity. Luis Patti is an iconic figure. Besides working in the police force, he entered local politics in the 1990s as a leader of the Federalist Union Party, and became the mayor of Escobar, a town in the province of Buenos Aires. During the first years of the Alfonsín government Patti faced several trials against alleged torture and assassination. These were put on hold, until the latest annulment of the amnesty laws.

Emilio is waiting for me at San Martin Central Station. $\mathrm{He}$ is fumbling with a flag decorated with a picture of Che Guevara. Emilio tells me that his compañeros (comrades) made it especially for this new human rights trial. We head off to the court, and Emilio seems animated. One block before the actual court building, HIJOS Capital (a local organization of children of the disappeared based in Buenos Aires) is prepping their rally. ${ }^{4}$ They are unloading loudspeakers from an old orange school bus and stringing tiny flags and colourful balloons, printed with 'trial' and 'punishment' in the trees and fences. The local media cameras are rolling and many (professional) photographers are taking pictures. At the back of the patch of grass, someone fires up a barbecue for lunch. The smoky scent of asado (barbecue) is slowly filling the air. Asados are a social custom in Argentina and mean far more than pieces of grilled meat. It is an act of solidarity and social belonging. Intrigued by the smoke, I lose sight of Emilio. He probably went off to greet some of his compañeros. I wander to the Federal Court. It is sealed off with fences and the police are guarding the entrance. Today only a lucky few are able to attend the opening of the trial. People from the neighbourhood are making themselves comfortable in the shade; many do not bother to access the actual court room.

As I walk back to the HIJOS gathering I look more closely at other things around me. Photos mocking Patti in the notorious black-and-white striped prisoner outfit fuse with children's games, like a hopscotch between truth and justice. People are tossing plastic handcuffs (instead of rings) at various counters depicting the armed forces. A game of darts has Patti's face for the bull's eye of the dartboard, and people are tossing at tins to 'win' the highest punishments (see Figures $1 \& 2$ ). Someone invites me

\footnotetext{
${ }^{4}$ Hijos por la Identidad y la Justicia contra el Olvido y el Silencio (Sons and Daughters for Identity and Justice against Oblivion and Silence).
} 
Figures $1 \& 2$
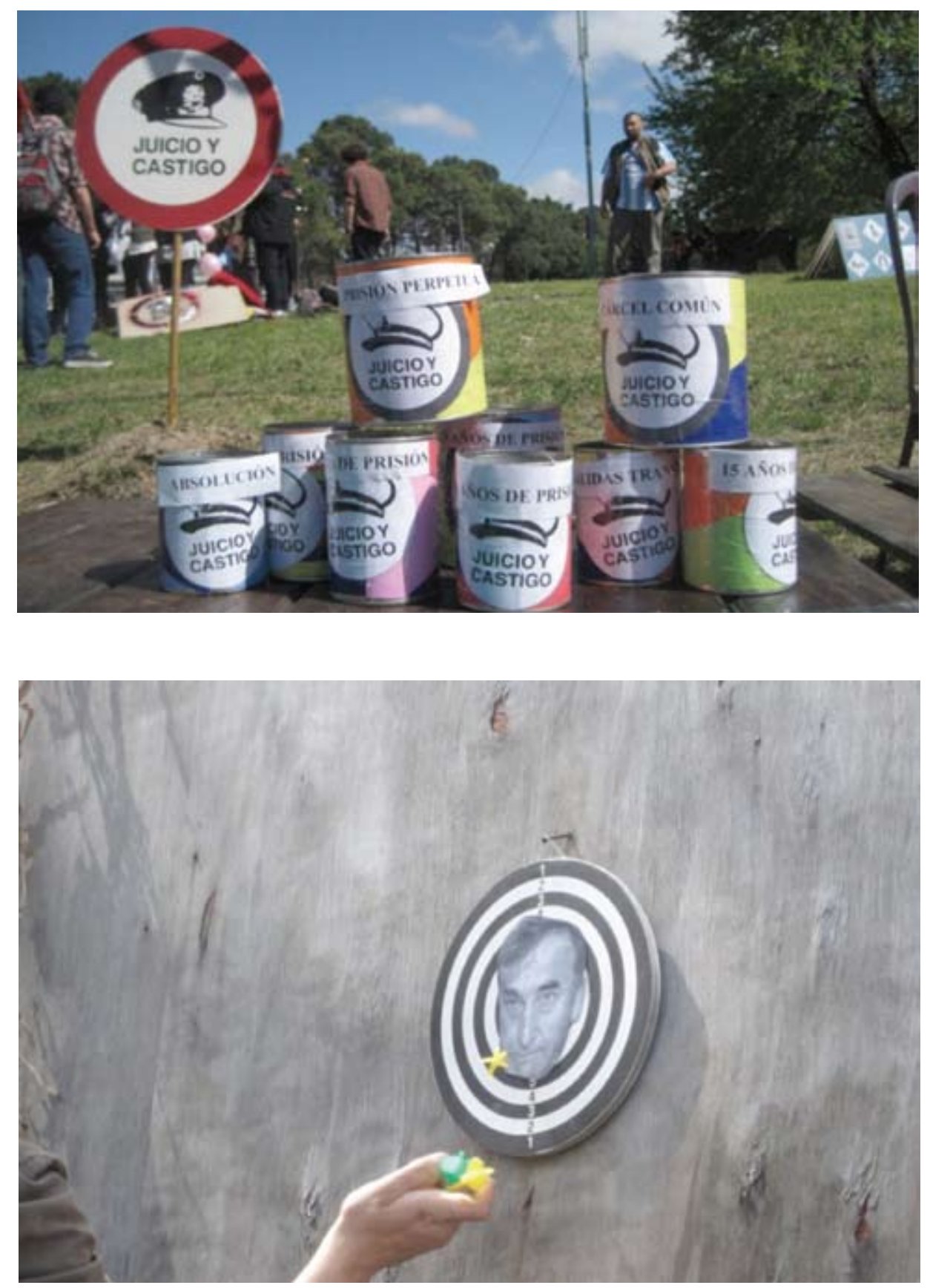

Photos by the author

The games were organized by HIJOS Buenos Aires at the opening of the Luis Patti trial at the Tribunal No. 1 at the Federal Court in the San Martin district, a province of Buenos Aires, on September 27, 2010. The top picture shows 'the tin toss.' Each tin can has a different penalty, such as life imprisonment, 15 years' imprisonment, common jail or acquittal. The bottom picture shows a game of Patti darts with Patti's face as the bull's eye. 
to play a game. I hesitate for a second, but turn the opportunity down. People around me laugh and cheer when someone's dart scores a bull's eye.

The choripanes (popular spicy sausages served on a bread roll) are sizzling on the barbecue when we hear a rumour that the main suspect, Luis Patti, has been brought into court on a stretcher, due to a severe illness. The rumour produces a simultaneous wave of laughter and indignation in the small crowd. People around me groan and smile, telling no one in particular that they find Patti's perhaps staged - appeal for pity outrageous. The festive atmosphere somehow matches my own mellow feeling. It changes only with the speech by the son of a disappeared, and a girl singing 'Como a los Nazis les va a pasar, a donde vayan los iremos a buscar' ('What happened to the Nazis, will happen to you, wherever you go, we will find you'). This is a famous protest song of the human rights groups in Argentina, often chanted at public demonstrations. Today people join in the chanting with less zeal.

When I speak with Tomás, a human rights lawyer, he tells me he is delighted with today's gathering. Unfortunately he has to return early to the city centre because he has to attend an important oral hearing. I ask Tomás to drop me off at the Plaza de Armas, where a handful of family members of the accused military are gathered. They are protesting against the human rights trials in front of the Ministry of Defence building. Their physical arena of dissent is right behind Plaza de Mayo where every Thursday since 1977 the mothers of the disappeared walk to demand information on the whereabouts of their children. Tomás looks at me and says with a laugh, 'Are you going to these fachos, smelling of our choris?!' Fachos derives from the word 'fascists'. In this context it means the conservative right who supported the authoritarian regime. Choris is just an colloquial abbreviation of choripanes. The big smile on Tomás's face expresses a kind of selfsatisfaction. I smile in return, and in an unreflective sense I understand immediately what Tomás just communicated. In retrospect I comprehend even more what Tomás's joke meant. He was laughing at the idea of a foreign researcher, smelling of the victims' choris, going to meet the relatives of the alleged perpetrators. They represent the legal other and my body bringing this choris smell into their comfort zone symbolizes another victory for the victims.

The derisive attempts to mock the main defendant Patti are only possible on the fringe of the legal world. Creating games that poke fun seems a way to fight boredom and avoid repetition, and attracts people to participate in the many human rights trials in the province of Buenos Aires. Informants from the human rights movement often explained that a festive atmosphere underlines their civilised search for justice. However, there is more at stake with these games and it is crucial to grasp the value of play as a cultural factor in life (Huizinga 1970:22). Humour is often considered a 'weapon of the weak' (Scott 1985). When little power is at your disposal, humour can provide space for subordinate persons to voice resistance (Fernandez \& Taylor Huber 2001: 17; Goldstein 2003: $10)$. But humour has been analysed from many different perspectives (Herzfeld 2001; Hutcheon 1994; Kidron 2010; Kuipers 2011; Pedrazzini 2010; Scott 2007). In general it is said that humour is another way of turning incongruities or distressing experiences into moments of non-serious play (Martin 2007: 19). Bakhtin argues that humour provides a way to silence certain emotions, as ironic wordplay often says the opposite of what is meant, and can be seen as a substitute for silence (Fernandez \& Taylor Huber 2001: 5).

Since the mid-1990s, HIJOS has struggled to end impunity related to the last dictatorship, and their former escraches (street protests to expose the alleged perpetrators of the last dictatorship) already had 'joking' features (Strejilevich 2010: 239). It is said that humour can realign power relations. It strengthens one paradigm at the expense of another, and affects the hegemonic status quo (Kidron 2010: 432; Kuipers 2011: 76). In the long run, humour can even produce social change to some extent (Kuipers 2011; Lewis 2006: 203). If we look more profoundly at this experience - the comical games, the cheerful response to the news that Luis Patti had been brought into court on a stretcher, and my body reeking with the smell of choris - and place it in its current political context, we can see important vicissitudes of meaning.

Under the current Kirchner government, the meaning of mockery regarding alleged perpetrators has changed. Such humour is a risky practice in a country still recovering from almost two decades of violence, chaos and impunity (Foster 1989: 61). Yet that day at Patti's trial shows that humour is not just a weapon of the weak, or confined to the fringe. As political constellations change, so too does the meaning of local satirical humour. What started as an alternative form of legal justice has now become an 'add on' to the current legal proceedings, with traces of - perhaps understandable, yet publicly denied - revenge and extra-legal retribution. Jokes and scornful performances provide an alternate space for rebelling against, judging and avenging the opponent, without altering or transgressing formal rules. They seem to be substitutes garnered from beyond the legal framework that shape the sense of justice people try to hang on to after collective violence. When physical aggression is forbidden by law, or simply impossible or undesirable, it can be replaced by efforts to make our opponent small, inferior, despicable or comic; and in a roundabout way we achieve the pleasure of overcoming him (Freud 1960: 102-103). Practices of humour function, so to speak, as an extrinsic moral law governing social interactions (Haynes 2006: 37).

\section{CONCLUSIONS}

Mockery of the last dictatorship in Argentina has changed over the years due to political changes in transitional justice policies and new forms of injustices. In the face of 
changing transitional justice politics and low faith in judicial power, it remains a valued practice. This humour is still an important element in the daily struggle against inconsistencies and injustices in Argentina (Cascioli 2005; Foster 1989; Fraticelli 2008; Pedrazzini 2010). Besides potentially providing relief, functioning like a coping mechanism or resistance strategy against powerful institutions such as the judiciary, playful aggression might also be part of this humour (Martin 2007: 19). It is a way of simultaneously communicating and silencing what produces discomfort, as Oring aptly notes (Martin 2007: 43). Humour definitely has a dark side - a two-face character (Freud 1960: 155). Furthermore, addressing delicate matters with jokes leaves room to deny meaning and escape accountability (Kuipers 2011: 71), as supposedly it is not intended to inflict direct physical harm (Martin 2007: 47).

These are all worthy insights, but this article primarily argues that the humour practices it describes provide access to complicated emotions in the lives of people burdened with (inherited) experiences of collective violence and impunity. Certainly, humour practices can account only partially for the emotions of others. Yet, paying close attention to comical expressions provides another valuable source of insights into the felt experiences of others. Ultimately, exploring local practices of humour can broaden knowledge about the tensions between what we do or do not see and experience in ethnographic fieldwork. Analysing the local meanings of a satirical magazine column, a smothered laugh, mocking games outside a court and the smell of choris on a researcher's body provide further insight into the emotions of others. Humour that at the beginning of my fieldwork seemed incomprehensible is a sound response to a moral and legal system that had long been incapable of addressing the grievances of the victims of the last dictatorship. Even now, when the court is finally addressing certain of these grievances, people still turn to ridicule to express emotions and thoughts that are excluded in formal legal interventions, and produce another, albeit momentary, sense of justice and comfort. 呫

\section{ACKNOWLEDGEMENTS}

I would like to thank my colleagues in the Department of Cultural Anthropology at Utrecht University and the academic research institute IDES (Instituto de Desarrollo Económico y Social) in Buenos Aires for their fruitful comments on earlier versions of this work. 


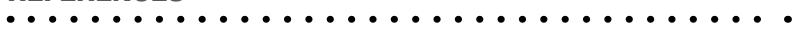

Abu-Lughod, L. (1986) Veiled Sentiments: Honor and Poetry in a Bedouin Society. Berkeley: University of California Press.

Al-Mohammad, H. (2011) 'Less Methodology more Epistemology Please: The Body, Metaphysics and "Certainty". Critique of Anthropology. 31(2): 121-138.

Arnould, V. (2006) 'Peace and Justice - Justice after Civil Wars: Truth Commissions and War Crimes Tribunals'. Studia Diplomatica. 59 (2): 141-160.

Bandes, S.A. (1999) The Passions of Law. New York: New York University Press.

Bandes, S.A. \& Blumenthal, J.A. (2012) 'Emotion and the Law'. Annual Review of Law and Social Science. 8: 161-181

Beatty, A. (2010) 'How Did it Feel for You? Emotion, Narrative, and the Limits of Ethnography'. American Anthropologist. 112 (3): 430-443.

Bloomfield, D., Barnes, T. \& Huyse, L. (2003) Reconciliation after Violent Conflict: A Handbook. Stockholm: International IDEA.

Briggs, J. (1970) Never in Anger: Portrait of an Eskimo Family. Cambridge: Harvard University Press.

Buckley, F.H. (2003) The Morality of Laughter. Ann Arbor: The University of Michigan Press.

Cascioli, A. (2005) La Revista HUMOr y la Dictadura. Buenos Aires: Musimundo.

Cerwonka, A. \& Malkki, L.H. (2007) Improvising Theory: Process and Temporality in Ethnographic Fieldwork. Chicago: The University of Chicago Press.

Corin, E. (2007) 'Personal Travels through Otherness'. Pp. 239-261 in A. McLean \& A. Leibing (eds.) The Shadow Side of Fieldwork: Exploring the Blurred Borders between Ethnography and Life. Malden: Blackwell Publishing.

Davies, J. \& Spencer, D. (2010) Emotions in the Field: The Psychology and Anthropology of Fieldwork Experience. Stanford: Stanford University Press.

Elster, J. (2004) Closing the Books: Transitional Justice in Historical Perspective. Cambridge: Cambridge University Press.

Fernandez, J.W. \& Taylor Huber, M. (2001) 'Introduction: The Anthropology of Irony'. Pp. 1-37 in J.W. Fernandez \& M. Taylor Huber. (eds.) Irony in Action: Anthropology, Practice, and the Moral Imagination. Chicago: The Uni- versity of Chicago Press.

Findlay, M. \& Henham, R.J. (2005) Transforming International Criminal Justice: Retributive and Restorative Justice in the Trial Process. Cullompton: Willan.

Finkel, N.J. \& Parrot, W.G. (2006) Emotions and Culpability: How the Law is at Odds with Psychology, Jurors, and Itself. Washington: American Psychological Association.

Foster, D.W. (1989) From Mafalda to Los Supermachos: Latin American Graphic Humor as Popular Culture. Boulder: Lynne Rienner Publishers.

Fraticelli, D. (2008) 'La Revista Barcelona y el Humor Local’. Revista Letra Imagen Sonido. 1 (2): 117-130.

Freud, S. (1960 [1905]) Jokes and their Relation to the Unconscious. trans. J. Strachey \& A. Freud. London: The Hogarth Press.

Gieser, T. (2008) 'Embodiment, Emotion and Empathy: A Phenomenological Approach to Apprenticeship Learning'. Anthropological Theory. 8 (3): 299- 318.

Goldstein, D.M. (2003) Laughter out of Place: Race, Class, Violence, and Sexuality in a Rio Shantytown. Berkeley: University of California Press.

Hage, G. (2010) 'Hating Israel in the Field: On Ethnography and Political Emotions'. Pp. 129-154 in J. Davies \& D. Spencer (eds.) Emotions in the Field: The Psychology and Anthropology of Fieldwork Experience. Stanford: Stanford University Press.

Haynes, D. (2006) 'The Persistence of Irony: Interfering with Surrealist Black Humour'. Textual Practice. 20 (1): 25-47.

Herzfeld, M. (2001) 'Irony and Power: Toward a Politics of Mockery in Greece'. Pp. 63-83 in J.W. Fernandez \& M. Taylor Huber (eds.) Irony in Action: Anthropology, Practice, and the Moral Imagination. Chicago: The University of Chicago Press.

Huizinga, J. (1970 [1949]) Homo Ludens. Bungay: Paladin.

Hutcheon, L. (1994) Irony's Edge: The Theory and Politics of Irony. London: Routledge.

Huyssen, A. (2001) 'Of Mice and Mimesis: Reading Spiegelman with Adorno.' Pp. 28-42 in B. Zelizer (ed.) Visual Culture and the Holocaust. New Brunswick, NJ: Rutgers University Press.

Jackson, M. (1989) Paths toward a Clearing: Radical 
Empiricism and Ethnographic Inquiry. Bloomington: Indiana University Press.

Kidron, C.A. (2010) 'Embracing the Lived Memory of Genocide: Holocaust Survivor and Descendant Renegade Memory Work at the House of Being'. American Ethnologist. 37 (3): 429-451.

Kuipers, G. (2011) 'The Politics of Humour in the Public Sphere: Cartoons, Power and Modernity on the First Transnational Humour Scandal'. European Journal of Cultural Studies. 14: 63-80.

Leavitt, J. (1996) 'Meaning and Feeling in the Anthropology of Emotions'. American Ethnologist. 23 (3): 514539.

Lewis, P. (2006) Cracking up: American Humor in a Time of Conflict. Chicago: The University of Chicago Press.

Lorimer, F. (2010) 'Using Emotion as a Form of Knowledge in a Psychiatric Fieldwork Setting'. Pp. 98-126 in J. Davies \& D. Spencer (eds.) Emotions in the Field: The Psychology and Anthropology of Fieldwork Experience. Stanford: Stanford University Press.

Lozada, M. (2008) Sobre el Genocidio: El Crimen Fundamental. Buenos Aires: Capital Intelectual.

Luhrmann, T. (2010) 'What Counts as Data?' Pp. 212-238 in J. Davies \& D. Spencer (eds.) Emotions in the Field: The Psychology and Anthropology of Fieldwork Experience. Stanford: Stanford University Press.

Lupton, D. (1998) The Emotional Self: A Socio-cultural Exploration. London: Sage Publications.

Lutz, C. (1988) Unnatural Emotions: Everyday Sentiments on a Micronesian Atoll and Their Challenge to Western Theory. Chicago: The University of Chicago Press.

Lutz, C. \& White, G.M. (1986) 'The Anthropology of Emotions'. Annual Review of Anthropology. 15: 405436.

Martin, R.A. (2007) The Psychology of Humor: An Integrative Approach. London: Elsevier Academic Press.

Maroney, T.A. (2006) 'Law and Emotion: A Proposed Taxonomy of an Emerging Field'. Law and Human Behavior. 30: 119-142.

Minow, M. (1998) Between Vengeance and Forgiveness: Facing History after Genocide and Mass Violence. Boston: Beacon Press.

- (1999) 'Institutions and Emotions: Redressing Mass Violence'. Pp. 265-281 in S. Bandes (ed.) The Passions of Law. New York: New York University Press.
Nino, C.S. (1996) Radical Evil on Trial. New Haven: Yale University Press.

Nussbaum, M.C. (2004) Hiding from Humanity: Disgust, Shame, and the Law. Princeton: Princeton University Press.

Osiel, M.J. (1997) Mass Atrocity, Collective Memory, and the Law. New Brunswick, NJ: Transaction Publishers.

Pedrazzini, A. (2010) 'Absurdo, Bulo e Ironía: Pilares del Humor Escrito del Suplemento Argentino Sátira/12'. Perspectivas de la Comunicación. 3 (2): 84-106.

Rebhun, L.A. (1999) The Heart is Unknown Country: Love in the Changing Economy of Northeast Brazil. Stanford: Stanford University Press.

Robben, A.C.G.M. (2005) Political Violence and Trauma in Argentina. Philadelphia: University of Pennsylvania Press.

Roht-Arriaza, N. \& Mariezcurrena, J. (2006) Transitional Justice in the Twenty-First Century: Beyond Truth versus Justice. Cambridge: Cambridge University Press.

Rosaldo, M. (1984) 'Toward an Anthropology of Self and Feeling'. Pp. 137-157 in R.A. Sweder \& R.A. LeVine (eds.) Culture Theory: Essays on Mind, Self, and Emotion. Cambridge: Cambridge University Press.

Scheper-Hughes, N. (1992) Death Without Weeping: The Violence of Everyday Life in Brazil. Berkeley: University of California Press.

Scott, J.C. (1985) Weapons of the Weak: Everyday Forms of Peasant Resistance. New Haven: Yale University Press.

Scott, T. (2007) 'Expression of Humour by Emergency Personnel Involved in Sudden Death Work'. Mortality. 12 (4): 350- 364.

Strejilevich, N. (2010) 'Performative Memorial Sites and Resistance in Argentina'. Peace Review: A journal of Social Justice. 22: 236-243.

Teitel, R.G. (2000) Transitional Justice. New York: Oxford University Press.

Trigona, M. (2006) 'Missing Witness Awakens Dark Past'. [online] Available at http://www.worldpress.org/ Americas/2531.cfm [Accessed on 17 October 2011].

Van Drunen, S. (2010) Struggling with the Past: The Human Rights Movement and the Politics of Memory in Post-Dictatorial Argentina (1983-2006). Amsterdam: Rozenberg Publishers.

White, G.M. (2010) 'Moral Discourse and the Rhetoric 
of Emotion'. Pp. 68-82 in R.A. Levine (ed.) Psychological Anthropology: A Reader on Self in Culture. Malden: Wiley-Blackwell.

Wierzbicka, A. (1999) Emotions across Languages and Cultures: Diversity and Universals. Cambridge: Cambridge University Press.

Wikan, U. (1990) Managing Turbulent Hearts: A Balinese Formula for Living. Chicago: The University of Chicago Press. 